\title{
Editorial
}

\section{Induction of anaesthesia in the infant}

The planning and management of an anaesthetic is intended to anticipate potential complications, as is the selection of drugs and techniques. Anaesthetic morbidity and mortality in the infant age group exceeds that of older children or adults. Even when life-threatening congenital defects are excluded, the risk of complications directly related to anaesthesia may be up to five to ten times greater than in older age groups.,

In this issue of the Joumal, Wamer et al. describe and discuss the cases of two awake infants who developed negative pressure pulmonary oedema during induction of anaesthesia with a non-depolarizing muscle relaxant. Although the pathophysiology of negative pressure pulmonary is not completely understood, it has been described in various pathological and iatrogenic states associated with acute upper airway obstruction accompanied by maximal inspiratory effort. The pulmonary oedema is noted immediately following the relief of the obstruction and usually resolves with use of positive pressure ventilation, PEEP, and diuretic therapy. ${ }^{3}$

Normal infants present unique anatomical, physiological and technical problems to the anaesthetist. The relatively large tongue, short neck, prominent occiput, and position of the larynx are some of the anatomical features about which one has to be aware. A high metabolic rate, a relatively small alveolar surface area, small FRC and low haemoglobin with reduced oxygen carrying capacity, are among the factors which allow hypoxaemia to develop rapidly. Maintenance of an unobstructed airway in an obtunded infant demands technical expertise; not the least of the technical problems is securing intravenous access in a crying, squirming baby. It is in the anticipation of these problems that some have recommended that parents should be dissuaded from being present during induction of infants. ${ }^{4}$

In recent years, the introduction of faster-acting, more rapidly metabolized non-depolarizing muscle relaxants with fewer side effects has been beneficial. They have become widely used in paediatric anaesthesia. However,

Department of Anaesthesia, CHEO, University of Ottawa, Ottawa, Ontario. before the use of any muscle relaxant, it is obligatory to have the skill to ventilate the patient's lungs with a bag and mask. In no normal patient is this precept more important than in the infant age group. The rapidity with which hypoxaemia can develop has already been alluded to, and the technical finesse required to maintain the airway appropriately can be difficult to master, as Dr. Warner's paper vividly describes.

Many paediatric anaesthetists advocate an intravenous induction technique for all age groups when it is appropriate. When done with facility, it is rapid and safe. A slower but perhaps safer technique in less experienced hands is a "step-by-step" approach using high inspired oxygen concentrations with two to three per cent halothane. This allows time to optimize control of the airway and to determine fully one's ability to assist ventilation prior to the administration of a muscle relaxant or other depressant drugs. The choice of induction technique is dependent on various factors, not the least of which is the experience and skill of the anaesthetist. What is a reasonable technique for an anaesthetist fully conversant with the problems of the infant may be disastrous in less expert hands.

Complications will inevitably occur. Their occurrence can only be minimized, if one practises within the limitations of one's knowledge, training, skills and work environment.

\section{L'induction anaesthési- que chez le bébé, un art}

La prévention des complications doit faire partie intégrante de la planification d'une anesthésie et ce, surtout lorsque on a affaire à un groupe à risque. Or, même en l'absence de malformation congénitale sérieuse, le risque de complications anesthésiques est de cinq à dix fois plus élevé avant l'âge d'un an. ${ }^{1,2}$ 
Dans cette édition, Warner et al. décrivent deux cas d'œdème pulmonaire par pression négative survenus chez des bébés éveillés lors de l'injection de myorelaxant non-dépolarisant. On comprend mal la pathophysiologie de ce type d'œdème, mais on peut le rencontrer quand une obstruction aiguë des voies respiratoires est combinée à un effort inspiratoire maximum. L'œdéme se développe classiquement juste après la levée de l'obstruction et peut être traité par des diurétiques, la ventilation par pression positive et le PEEP. ${ }^{3}$

Les bébés normaux présentent plusieurs traits anatomiques pouvant rendre difficile le travail de l'anesthésiste : une grosse langue, un cou court, un occiput proéminent et un larynx placé haut. De plus, leur métabolisme important couplé à une faible surface alvéolaire, à une petite CRF et à une anémie relative favorise la survenue rapide de l'hypoxémie. Il faut de la technique pour assurer la perméabilité des voies respiratoires d'un bébé inconscient et c'est un art que d'installer un cathéter intraveineux chez celui qui se débat. A cause de ces problémes potentiels, certains croient que les parents n'ont pas leur place en salle d'induction. ${ }^{4}$

L'introduction récente de myorelaxants nondépolarisants à action plus rapide et plus courte en a popularisé l'usage en anesthésie pédiatrique. Toutefois, avant d'injecter quelque myorelaxant que ce soit, il faut avoir la certitude de pouvoir assurer la ventilation au masque de tout patient, a fortiori des bébés, eux qui sont susceptibles à l'hypoxémie et chez qui la perméabilité des voies respiratoires peut poser problème.

Lorsque qu'appropriée, plusieurs anesthésistes préférent la voie intraveineuse pour l'induction anesthésique des patients de tous âges. C'est une voie rapide et sûre dans la plupart des cas. Cependant, une induction graduelle au masque avec une concentration élevée d'oxygéne et de l'halothane est certes plus lente mais aussi moins risquée entre des mains moins expérimentée. Cette dernière approche donne le temps d'assurer la perméabilité des voies respiratoires et d'évaluer la facilité du support ventilatoire au masque avant d'injecter myorelaxants et autres dépresseurs. L'expérience et l'habilité de l'anesthésiste va donc devoir moduler le choix de la technique d'induction anesthésique des bébés.

L'occurence de complications ne disparaitra pas mais elle peut être minimsée si l'anesthésiste est conscient des limites de ses connaissances, de son habilité et de ses ressources.

\section{References}

1 Gregory GA. Paediatric Anesthesia. New York; Churchill Livingston, 1983; 1-9.

2 Graff TD, Philips $O C$, Benson DW, Kelley E. Factors in pediatric anesthesia mortality. Anesth Analg, 1964; 43: 407-14.

3 Warner LO, Beach TP, Martino JD. Negative pressure pulmonary oedema sccondary to airway obstruction in an intubated infant. Can J Anaesth 1988; 35: 507-10.

4 Maxwell $L G$, Wetzel $R C$. Induction techniques in pediatric ancsthesia. Anesthesiology Report 1988; 1: 110-9. 